\title{
Accounting Frauds: A Review of Literature
}

\author{
Clement C.M. Ajekwe ${ }^{1 *}$, Adzor Ibiamke ${ }^{1}$ \\ ${ }^{1,}$ Department of Accounting, Benue State University, Makurdi
}

\begin{abstract}
The business community requires transparent corporate reports to ensure that investment decisions are not based on materially misstated financial statements. This implies that corporate managers, auditors, board of directors, investors and regulatory agencies urgently need to be able to detect and prevent potential earnings frauds. The literature review seeks to improve understanding of the fraudulent financial statement anatomy, its factors, motivations and antecedents- the knowledge of which can improve our detection and prevention ability. The "fraud triangle" is portrayed as an efficient model for understanding antecedents to fraud. Concurring with Zahra, Priem and Rasheed (2005), the paper calls for further research to understand the motivational factors of fraud behaviour as well as adopting forensic accounting techniques to enhance the probability of detecting fraud in a timely, cost effective manner.
\end{abstract}

Key Words: Accounting frauds, fraud triangle, financial fraud

\section{INTRODUCTION}

Publicly traded companies are required to prepare and issue financial statements that fairly reflect their performance and financial position. While the vast majority of public companies provide financial reports that are free from material misstatements; fraud continues to exist including the well publicized frauds at Enron and WorldCom among others. In the literature, two types of accounting frauds are identified: (i) fraud committed by top management to maintain an illusion of high performance by the company in order to raise capital for their firms and mislead investors and others (e.g., auditors, board of directors and the general public), and (ii) fraud committed by top or middle management for personal gain, to earn bonuses and enhanced compensation. Accounting fraud is an issue of great concern to the business community including: (a) auditors who are engaged to render an opinion as to whether the financial reports fairly present the company's financial position and results of operations in conformity with established standards; (b) board of directors who bear the primary responsibility for the preparation and content of the financial reports; (c) investors and potential investors; (d) corporate managers; and (e)the general public, and as a result, regulators, legislators and other public policy makers. These parties all have an interest in preventing and detecting fraud before investment decisions are made on materially misstated financial statements. This paper critically analyses literature based on the factors, motivation and antecedents of fraudulent financial reporting. The overall objective for the review is to improve understanding of anatomy of fraud, thereby improving the ability to detect fraud.

The structure of the paper is as follows: The definition and distinction between earnings management and fraud is reviewed in the next section. The fraud triangle, parties commonly involved in financial reporting fraud as well as the fraud (type and evidence) schemes deployed to perpetrate fraud is reviewed in sections 3 to 5. Then the incentives and motivations for committing fraud, predictors of fraud as well as consequences of committing financial reporting fraud are reviewed in sections 6 and 7. Consequences of fraud and conclusions from sections 8 and 9 conclude the paper.

\section{DEFINITIONS OF EARNINGS MANAGEMENT AND ACCOUNTING FRAUD}

Accounting fraud differs from other frauds in that it is committed usually by management to deceive financial statement users while misappropriation of assets is committed against an entity, most often by employees (Guy \& Pany, 1997: 4). Accounting fraud is the intentional, material misstatement of financial statements or financial disclosures or the perpetration of an illegal act that has a material direct effect on the financial statements or financial disclosure (Beasley, Carcello, Hermanson \& Neal, 2010: 7). The classification of an action as being fraudulent may depend on the motivation behind it (Brennan \& Hennessey, 2001:61).

Young (2000) suggests that accounting fraud does not start with dishonesty; rather, it may begin with pressure to meet financial targets and the fear that failure to meet these targets will be viewed as unforgivable. Alternatively, the perpetrator of fraud may be driven by dishonesty and personal gain (for example, to protect bonuses) rather than by pressure from the organization. This resonates with Cressey's fraud triangle which identifies three factors: private non-shareable incentives or pressure, contextual opportunities to commit fraud; 
and ability to rationalize fraud. It may start small (KPMG, 2004), in areas which contain ambiguities or allow alternative ways to record the operations of an entity. For instance, any depreciation method that systematically and rationally allocates the cost of the asset over its useful life is allowed by accounting standards. Management may exploit such a flexibility to present a financial picture that meets their financial targets rather than economic reality of the firm's transactions. Most accounting fraud schemes involve "earnings management" which does not always involve outright violations of accounting standards; more often than not, entities manage earnings by choosing accounting policies that bend the accounting rules to attain earnings targets. Thus the dividing line between earnings management which does not violate accounting rules/standards and "earnings manipulation" which amounts to fraudulent accounting is narrow. Next, earnings management is distinguished from fraudulent accounting.

\subsection{Earnings Management and Fraud}

Accounting academics often have different perceptions of earnings management than do practitioners and regulators (Dechow \& Skinner (2000). For example, Healy and Wahlen's (1999:368) widely accepted definition of earnings management is that: Earnings management occurs when managers use judgment in financial reporting and in structuring transactions to alter financial reports to either mislead some stakeholders about the underlying economic performance of the company or to influence contractual outcomes that depend on reported accounting numbers Despite the wide acceptance of this definition, it centres on management intent to (1) mislead stakeholders about economic performance of the company and (2) influence contractual outcomes that depend on reported accounting numbers; it is difficult to measure it directly since it cannot be observed directly. Accounting standards are not meant to be a straight jacket hence management is allowed flexibility of accounting which is essential to innovation (Levitt, 1998). An unintended consequence of allowing accounting flexibility is that it gives management the latitude to "manage earnings" by altering its accounting policy to select those accounting principles that benefit it most (provided it is disclosed). Examples are many and include the following:

i. Changing depreciation method from an accelerated method to a more conservative straight line method and vice versa;

ii. Changing the useful lives or the estimates of salvage value of assets;

iii. Determining whether/when assets have become impaired, and are required to be reserved against or written off.

iv. Determining the appropriate allowance required for uncollectable accounts receivable;

v. Choosing an appropriate method of inventory valuation (FIFO, AVCO or specific identification).

vi. Determining whether a decline in the market value of an investment is temporary, or permanent, and

vii. Estimating the write downs required for investments.

While clear definitions of "earnings management" are difficult to discern from practitioners' or regulators' statements or pronouncements; an extreme form of earnings management, that is, accounting fraud is well defined (again in terms of management intent) by the National Association of Certified Fraud Examiners, [NACFE] (1993:12) as follows:

The intentional deliberate, misstatement or omission of material facts, or accounting data, which is misleading and when considered with all the other information made available would cause the reader to change or alter his or her judgment or decision. In their speeches and writings, regulators, such as the Securities and Exchange Commission (SEC), seem to suggest that financial reporting choices that explicitly violate accounting standards can clearly constitute both fraud and earnings management; while systematic choices made within accounting standards constitute earnings management. Certain techniques have been identified as clearly not being within the acceptable parameters of accounting rules. These unacceptable techniques are generally those that inflate earnings, create an improved financial picture, or conversely, mask a deteriorating financial picture. The techniques which constitute financial frauds include (1) "big bath" charges, (2) creative acquisition accounting, (3) "cookie jar" liability reserves, (4) use of materiality to record small but intentional misstatements in the financial statements and (5) revenue recognition irregularities. The notion that earnings management can occur within the bounds of accounting standards is consistent with the academic definition described by Dechow and Skinner (2000); who have distinguished between managerial choices that are fraudulent and those that comprise aggressive, but acceptable ways in which managers can exercise their accounting discretion. They make the point that there is a clear conceptual distinction between fraudulent accounting practices (that clearly demonstrate intent to deceive) and those judgments and estimates that fall within acceptable practice and which may comprise earnings management depending on managerial intent. 
Figure 1 depicts how Dechow and Skinner (2000) distinguished between earnings management and accounting fraud.

\begin{tabular}{|c|c|}
\hline $\begin{array}{l}\text { "Conservative" } \\
\text { Accounting }\end{array}$ & $\begin{array}{l}\text { WITHIN GAAP } \\
\text { Overly aggressive recognition of provisions and reserves } \\
\text { Over valuation of acquired in-process R\&D in purchase } \\
\text { acquisitions } \\
\text { Overstatement of restructuring charges and asset write offs }\end{array}$ \\
\hline "Neutral" Earnings & Earnings that result from a neutral operation of the process \\
\hline $\begin{array}{l}\text { "Aggressive"/ } \\
\text { "Creative" } \\
\text { Accounting }\end{array}$ & $\begin{array}{l}\text { Understatement of the provision for bad debts } \\
\text { Drawing down provisions or reserves in an overly aggressive } \\
\text { manner }\end{array}$ \\
\hline $\begin{array}{l}\text { "Accounting } \\
\text { Fraud" }\end{array}$ & $\begin{array}{l}\text { VIOLATES GAAP } \\
\text { Recording sales before they are "realizable" recording fictitious } \\
\text { assets, backdating sales invoices, overstating inventory by } \\
\text { recording fictitious inventory }\end{array}$ \\
\hline
\end{tabular}

\section{THE FRAUD TRIANGLE}

The conceptual framework for understanding and detecting accounting fraud is the so called "Fraud Triangle". According to that framework, three major drivers underlie most corporate frauds: opportunity, motivation and rationalization. Opportunity implies a control environment with weak internal controls that can easily by overridden by top management. Motivation relates to individual incentives that put much pressure or emphasis on performance or external pressure to meet earnings or budget expectations. Finally, rationalization reflects the ability of individuals who are involved in frauds to adopt an attitude that deflects blame or responsibility (e.g., "it will not hurt anyone; we are so close to making our numbers" or "I am entitled to it because I work very hard").

Hogan, Rezaee, Riley and Velury (2008:16) in their synthesis of accounting fraud literature find that academic writings largely support the fraud triangle:

1. Pressures to meet analysts forecast, rapid growth, compensation incentives, stock options, the need for financing and poor performance increase the likelihood of accounting fraud (Bell \& Carcello, 2000; Rezaee 2005; Erikson, Hanlon \& Maydew 2006)

2. Effective corporate governance, including the board of directors, audit committee, and internal controls, and also the external auditor, play key roles in reducing the opportunity to commit fraud (Dechow, Sloan \& Sweeney, 1996; Beasley, 1996; Farber, 2005; Abbot, Parker \& Peters, 2004). In addition, external auditors play a role in reducing opportunities to manage earnings or commit fraud (Becker, DeFond, Jiambalvo \& Subramanyam, 1998; Francis, Maydew \& Sparks, 1999; Carcellos \& Nagy, 2002, 2004; Iyer \& Rama, 2004; Myers, Myers \& Omer, 2003).

3. Research is limited in the attitudes and rationalization area.

Carcello and Hermanson (2008) extend the fraud triangle by including a fourth element, the capability of the potential fraud perpetrator that is cited by Wolfe and Hermanson (2004). By adding the capability to commit fraud to the model, i.e., expanding the fraud triangle to the fraud diamond, it is recognised that although an individual may have an incentive to commit the fraud, an opportunity to commit fraud may exist, and the individual may be able to rationalize the behaviour, fraud will not occur unless the potential perpetrator has the personal capability (knowledge, skill, position, ability to handle stress etc) to commit the fraud. In other words, the potential perpetrator has to have the right skills to recognize and exploit a generic fraud opportunity.

\section{ACTORS MOST COMMONLY INVOLVED IN ACCOUNTING FRAUD}

Beasley et al. (2010) provide a comprehensive analysis of accounting fraud occurrences investigated by the US SEC between January 1998 and December 2007. That study confirmed that SEC had named the chief executive officer (CEO) and/or chief finance officer (CFO) for some involvement in 89 percent of the fraud cases. The question that arises from this situation is this: How are senior executives able to engage in financial fraud despite the presence of numerous control agents - board of directors (audit committee), internal and external auditors, etc., whose function it is to prevent those very abuses? How were the CEOs/CFOs able to override these controls? 
Black (2005:737) argues that CEOs in particular, are in a unique position to shape the firms internal and external controls. In effect, they are able to control the controllers - internal auditors, external auditors, board of directors etc. and create an illusion to "mimic a robustly healthy legitimate firm". CEOs and CFOs are typically perpetrators of the accounting frauds. They typically devise fraud schemes to minimize the likelihood of detection. Moreover, as auditors and other outside monitors change their technology to better detect fraud, the nature of the fraud scheme evolves to minimize the likelihood of detection (Bloomfield, 1997; Newman, Rhoades \& Smith, 1996; Wilks \& Zimbelman, 2004). As a result, fraud is difficult to detect, especially for auditors and outside monitors such as audit committee, investors and regulators. Black (2005:734) also takes the position that accounting fraud can be seen as a form of "control frauds"... "situations in which those who control firms or nations see the entity as a means to defraud customers, creditors, shareholders, donors or the general public". Accounting fraud, according to Black (2005:736), is an "optimal strategy" for many whitecollar crimes because

It simultaneously produces record (albeit fictional) profits and prevents the recognition of real loses. This combination reduces the risk of detection and successful prosecution because the CEO can use normal corporate mechanisms (e.g. pay raises, bonuses, stock options, dividends and appreciation in the value of the firm's stock) to convert the creditors funds to his personal use. The blessing by the top tier (Big 4) audit firm of the financial profits provides "cover" to the CEO against fraud prosecutions that would ever exist were he simply to embezzle funds. The spurious profits also aid the CEO's ability to enlist political aid and provide immense psychic value. From this perspective, the control agents - auditors, board of directors and regulators - are often allies of corporations who utilize them to "mimic a robustly healthy, legitimate firm".

Tillman and Indergaard (2007) studied the problem of control overrides in accounting fraud. The study involved creating a statistical portrait of the phenomenon of accounting fraud with data gleaned from several key sources:

1. A sample of firms compiled by the US General Accounting Office (GAO) that filed financial statements restatements in the period 1997-2002. Financial restatements occur when a company, prompted by auditors or regulators, or voluntarily, revises financial information that was previously reported. Filing financial restatements is an indication that (a) the firms internal control system is seriously breached or (b) Management has attempted to mislead readers of the statements (Kinney \& McDaniel, 1989; Richardson, Tuna \& $\mathrm{Wu}, 2002)$.

2. Class action securities fraud suits filed against those firms in relation to those restatements of earlier filed financial statements and

3. Documents related to actions taken against those firms by SEC.

Tillman and Indegaard (2007:2 - 3) found that:

At one extreme...organizations like Enron and Fannie Mae, where corruption was widespread and where directors, internal auditors, and the external auditors all knowingly facilitated the accounting deceptions. At the other extreme, one finds companies where corruption was limited to a small number of executives-often a CEO and CFO- who were able to deceive control agents, withholding information, until the damage was done. In between, one finds cases involving shifting combinations of corporate insiders and outsiders collaborating in, or acquiescing to schemes to mislead shareholders and regulators. In particular, the study found specific issues regarding auditors and directors as detailed below:

\subsection{Auditors}

Of all the control agents surrounding senior managers, one would expect that outside auditors; because of their professional obligations and because of their independence, would exert one of the most forceful constraints on senior executives' ability to file false financial statements. This expectation failed. Accounting firms that served as auditors for the sample issuing companies constituted $11 \%$ of all organizational defendants. Nearly one out of five (18\%) of the audit firms in the sample $(\mathrm{N}=374)$ had their auditors named in the class action suits or SEC actions. Furthermore, during the study period, Tillman and Indergaard (2007) found that corporate audits were dominated by five (Big-Five) accounting firms; who were the main defendants; 71 out of the 79 auditor defendants were Big-Five.

There are reasons to believe that in cases where auditors were accused of being involved in deceptive reporting, the frauds were more complex and more costly. It may be that large scale accounting frauds are difficult to perpetrate without at least tacit cooperation of auditors. One measure of complexity is the number of individuals and/or organizations named in the class action suits and SEC actions. In cases where accounting firms were named in class action suits or SEC actions the mean number of defendants was significantly higher, in fact more than twice as high (12.5 vs. 5.83), than it was where accounting firms were not named. Likewise, the median losses to shareholders as measured by changes in the market capitalization, were approximately 
twice as great ( $\$ 26.09$ million vs. $\$ 12.5$ million) in cases where accounting firms were named as when they were not.

\subsection{Directors}

Beasley et al. (2010) identified the board of directors, and particularly its audit committee as performing a critical role in preventing misrepresentations in financial reporting. Fama and Jensen (1983:315) argue that the board of directors is the most important source of internal control in a corporation. They argue, further, that external board members are effective as control agents because the "value of their human capital depends primarily on their performance as internal decision makers in other organisations and there is substantial devaluation of human capital when internal decision control breaks down..." By extension, there is a reputational lose to external board members who allow accounting fraud to occur on their watch and this cost leads to more material loses, such as removal from their prestigious board positions, or even legal liability. However, recent findings such as Srinivasan (2006) and Agrawal, Jaffee and Karpoff (1999) raise doubts about the extent to which "reputational costs" can serve as incentives of board members to closely monitor the actions of their senior executives.

The doubt is strengthened by the fact that two-fifths (40\%) of all firms in the Tillman and Indergaard (2007) sample, one or more members of the board of directors was named in a class action suit or SEC action. Most of those mentioned were external directors. Moreover, in nearly $18 \%$ of the cases, the Chairman of the Board was named. These findings suggest that in a large number of cases the board of directors did not fulfil its control function. One plausible explanation for why so many directors failed to exercise their control is that many may have been "bought off" with stock options, and even worse, many of those options may have been illegally back-dated to increase their value. In this scenario, board members turned a blind eye to accounting improprieties if they themselves were the beneficiaries of illegal, or at least improper, financial schemes.

As with cases where auditing firms were accused in formal actions; in firms where members of the board were named as defendants, the financial manipulation schemes were more complex and more costly than at other firms. One explanation for this finding is the simple fact that more complex and more costly frauds often take place over longer periods of time; and it is difficult to hide the frauds from members of the board of directors. In these cases, class action suits typically allege that directors either colluded in or were aware of the misreporting of financial results and did nothing to prevent it.

\section{FRAUD SCHEMES}

Accounting frauds occur through the fabrication of numbers in the accounts or the misapplication and wilful misinterpretation of accounting standards (Rezaee, 2002; Spathis, Doumpos \& Zopounidis, 2002). Financial statement frauds are intentionally designed by management to achieve pre-determined financial goals. Currently, auditing procedures can rarely detect fraud (Albrecht, Albrecht, \& Dunn, 2001; Loebbecke, Eining \& Willingham, 1989). It is therefore essentially important that auditors and other stakeholders know the relative frequencies with which various types of fraud occur (Nelson, Elliot \& Tarpley, 2003; Bonner, Palmrose, \& Young, 1998; Smith \& Kida, 1991; Heiman, 1990; Libby \& Frederick, 1990). With the knowledge of frequencies and patterns of fraud schemes, auditors, forensics, regulators, investors and academics etc could better understand the perpetration and concealment process of management fraud which can assist assessment of the overall fraud risk and the risk associated with various types of fraud schemes. Gao and Srivastava (2008) analysed fraud cases announced by US SEC in Accounting and Auditing Enforcements Releases (AAERs) issued between 1997 and 2002; and summarized frequencies of fraud schemes at the level of account schemes and evidence schemes. Account schemes are defined as those schemes that are relevant to manipulations of account balances such as revenue recognition on fictitious transactions. Evidence schemes refer to those schemes that are used by management to create (or hide) evidence in order to conceal account schemes and deceive auditors. The most frequent evidence schemes used by management to conceal fraud include: fake or altered documents, collusion with third parties, altered internal documents, hidden documents and/or information, and management misrepresentation. Furthermore, they (Gao \& Srivastava, 2008) observed several significant relationships among certain types of evidence schemes, account schemes, and company characteristics. First, the creation of fake documents is strongly related to recognition of fictitious revenues. Second, the collusion with third parties such as customers and distributors is also related to the recognition of fictitious revenues. Third, the use of altered internal documents is related to premature revenue recognition. Fourth, hidden documents/information is/are related to both premature revenue recognition and undervalued expenses/liabilities. And finally, management representations either in oral or written form is related to the account scheme of overvalued assets and undervalued expenses.

Besides the relationship between evidence schemes and account schemes Gao and Srivastava (2008) also found some interesting relationships between evidence schemes and company characteristics. For instance, 
companies in the computer industry (a new economy industry) are more likely to hide documents from auditors. In particular, side agreements with customers or distributors were hidden from auditors. The altered internal document scheme was deployed more in annual reports than in quarterly reports. Gao and Srivastavas (2008) analysis of the relationships among evidence schemes, account schemes and company characteristics could help the auditor predict evidence schemes used by management to conceal fraud. In addition, the analysis should help the auditor direct his/her attention to the audit evidence that might have been manipulated to conceal fraud, and thus help in the design of special procedures in response to potential fraud schemes. Beasley et al. (2010) identified improper revenue recognition as the most common fraud technique, followed by the overstatement of existing assets or capitalization of expenses. As Beasley et al. (2010) reported, companies employed a variety of techniques to improperly recognize revenue including the following: (a) sham sales, (b) conditional sales, (c) round-tripping or recording loans as sales, (d) bill and hold transactions (e) premature revenues before all the terms of the sale were completed (f) improper cut-off of sale, (g) improper use of the percentage of completion method (h) unauthorized shipments and (i) consignment sales.

\section{INCENTIVES/ MOTIVATIONS FOR COMMITTING FRAUD}

The Report of the National Commission on Fraudulent Financial Reporting (1987) revealed that financial reporting fraud usually occurs as the result of certain environmental, institutional or individual forces and opportunities. These forces and opportunities add pressures and incentives that encourage individuals and companies to engage in financial reporting fraud. If the right combustible mixture of forces and opportunities is present financial reporting fraud may occur. A frequent incentive for financial reporting fraud is the desire to obtain a higher price from a stock or debt offering or to meet the expectations of investors; i.e. capital market pressures. Several studies have investigated how efforts by senior managers to raise capital at low costs have resulted in pressure to engage in earnings manipulation (Dechow, Sloan, \& Sweeney, 1996, Richardson, Tuna \& Wu 2002). In these cases, managers want to maintain an illusion of high performance by their companies in order to raise capital for their firms.

One of the clear themes that emerged out of recent accounting scandals has been the way executive compensation that is tied to a firm's performance can provide incentives for accounting fraud. This proposition has been tested in a number of studies, which have generally found support for a notion that firms whose executives are given performance-based compensation in the form of stock options or bonuses, are much more likely to file restatements (Kedia, 2003), be subject to actions by SEC (Erickson, Hanlon and Maydew, 2006) or to be the subject of class action suit (Peng \& Roel, 2004).

A related issue has to do with insider trading by senior executives. In a number of highly publicized cases of accounting fraud, there was evidence that executives sold their stock in their firms ahead of public release of negative information about the firm's performance. Summers and Sweeney (1998) examined a sample of 51 companies that had been identified as being involved in accounting fraud between 1980 and 1987. These firms were compared to a control sample of non-fraudulent companies. Their analysis provides evidence that "insiders in companies with fraudulent financial statements reduce their net position in the entity's stock through a high level of stock sales activity" (Summers \& Sweeney, 1998:132). Similarly, Beneish (1999) focused his study on the extent to which senior managers at firms accused of earnings management sell their stock in the firm during the period in which earnings are manipulated. Based on the analysis of 64 firms that were either accused by the SEC or identified by the media as engaging in earnings manipulation in the period 1987-1993, Beneish found that compared with the control group of firms not accused of earnings manipulation, managers in the companies in his sample were much more likely to have sold their stock at inflated prices and exercised options. Beneish (1999) and Dechow, Sloan and Sweeney, (1996) examine fraud incentives related to debt covenant hypotheses. In accounting fraud and/or earnings management literature, the debt covenant hypothesis predicts that when firms are close to violating debts covenants, managers will use income increasing discretionary accruals to avoid violating the covenants (Dechow \& Skinner, 2000). Beneish (1999) and Dechow et al. (1996) hypothesize a positive relationship between demand for external financing and fraud, and between incentives related to avoiding debt covenant violations and fraud. Demand for external financing is measured in both studies as whether the difference between cash flow from operations and average capital expenditure to current assets is less than -0.5 and whether securities were issued in the fraud period. Incentives related to avoiding debt covenant violations are measured in both studies using leverage and actual instances of technical default. The results of the studies are mixed, with one study (Dechow et al.,1996) finding support for the hypothesized relationships and the other (Beneish, 1999) finding no support.

Firm performance, and consequently market value, is partially determined by the firms' ability to meet or exceed analyst expectations. Managers, therefore, have incentives to manipulate earnings to meet or exceed analyst forecasts when these forecasts would not otherwise have been met or exceeded (Burgstaher \& Eames, 2006). Managers can manipulate earnings to meet or exceed analyst forecasts by managing earnings or by committing fraud, (Feroz, Park \& Pastens, 1991).A number of studies have tested the theory that the 
composition of corporate boards influences the likelihood that the firm will engage in earnings manipulation. Research by Beasley (1996) and Klein (2002) demonstrates that the more "independent" boards are, as measured by the proportion of outside directors, the less likely they are to manipulate earnings. A study by Dechow, Sloan and Sweeney (1996) examined AAERS filed against 92 firms in the period 1982-1992. The characteristics of these firms were compared to those of a matched sample of firms that were not accused of earnings manipulation during the same period. It was found that firms accused of manipulating earnings were (1) more likely to have boards of directors dominated by management and (2) more likely to have a CEO who simultaneously serves as chairman of the Board (Dechow, Sloan \& Sweeney, 1996).

\section{FRAUD PREDICTORS}

Companies with a higher risk of commitment of accounting fraud tend to display specific behavioural characteristics (du Toit, 2008). If this is proved to be the case, such characteristics could be integrated into a model of characteristics which auditors, managers and other interested parties can be aware of as potential indicators to assist them in the detection and identification of fraud. Albrecht et al.(2004) identify nine factors which together create the "perfect fraud storm": a booming economy (which hides the fraud), moral decay, misplaced executive incentives, unachievable expectations of the market, pressure of large borrowings, rulebased accounting standards, opportunistic behaviour of audit firms, greed on the part of a wide variety of groups of people and educator failures. These nine factors are analyzed by reference to the Cresseys (1953) fraud triangle of pressure to commit fraud, opportunity to commit fraud and inclination to rationalise fraud. The authors also examined these factors against agency and stewardship theories. Albrecht et al. (2004) conclude from their analysis that managers who identify with a stakeholder perspective rather than with an agency theory perspective are less likely to commit fraud. Loebbecke et al. (1989) designed a fraud prediction model based on conditions in the entity, manager motivation and manager attitude. Bell and Carcello (2000) used the same fraud sample as Loebbecke et al. (1989) and contrasted it with non-fraud sample in order to consider the presence or absence of "red flags" as assessed by auditors. Some organizational factors identified as likely contributors to financial reporting fraud include; a weak control environment, rapid growth, inadequate or inconsistent profitability, management placing undue emphasis on meeting earnings forecast, and ownership status (public or private companies). Beasley et al. (2000) investigated corporate governance differences in a sample of fraud and non-fraud firms. They found that fraud firms were less likely to have an audit committee. Where one existed in the fraud firm, it tended to be less diligent and less independent; non-fraud firms had more outside directors on the audit committee than fraud firms. They also found that internal audit departments were less common in fraud firms. Prior fraud literature has identified improper revenue recognition and profit inflation as being the most primary form of accounting fraud (Beasley et al., 2010; KPMG, 2008; Telbergh, 2004; Beneish, 1999). Given that the revenue account is typically manipulated, unusual revenue levels or changes in revenue might be indicative of revenue fraud. However, considering that revenue varies from year to year and among firms for reasons other than fraud, straight revenue is a relatively noisy indicator of fraud. For example, it is very difficult to disentangle differences in revenue due to fraud from differences in revenue due to the size of the firm and the successfulness of the firm. To detect revenue fraud, SAS 99 highlights the need to analyze and identify unusual relationships involving revenue, for example, between revenue and production capacity. Prior research has included sales in various ratios that are not, typically, designed for the purpose of defecting fraud. Nevertheless, the results from these studies are largely consistent with fraud firms manipulating the revenue account. For example, sales growth, used as a proxy for firm growth, has been used as a predictor for fraud based on the idea that high-growth firms have incentives to sustain their high growth levels and that slow-growth firms have incentives to increase growth (Erickson et al.,2006; Brazel et al., 2007). The former study (Erickson et al., 2006) found a positive relationship between sales growth and fraud. Brazel et al. (2007) examined the relationship between performance improvements and fraud in more detail and found a negative relationship between sales growth using a non-financial measure and fraud. Together these results indicate that firms that increase revenue fraudulently are more likely have abnormally high growth rates, and that poor performing firms i.e. firms with low accrual growth rates, are more likely to commit fraud. Beneish (1999) profiled a sample of earnings manipulators identifying their distinguishing characteristics, from which a model for detecting manipulation was estimated. The model's variables, eight in all, are designed to capture either the effects of manipulation or preconditions that may prompt firms to engage in such activity. The results and empirical evidence suggest a systematic relation between the probability of manipulation and financial statement variables: The variables (ratios) are: (i) sales growth index (SGI), (ii) gross margin index (GMI), (iii) asset quality index (AQI), (iv) day's sales in receivables index (DSRI), (v) sales to general and administrative expenses index (SGAI). Other variables (ratios) are (vi) depreciation index (DI), (vii) leverage index (LINDEX) and (viii) total accruals to total assets (TATA). 


\section{CONSEQUENCES}

The Association of Certified Fraud Examiners (ACFE) (2008) examined 959 cases of occupational fraud and abuse for the period 2006 - 2008, and finds that fraud is extremely costly especially for small organizations. The medium fraud loss per organization was $\$ 175,000$; and more than $25 \%$ of the frauds involved losses exceeded \$1million. ACFE (2008) also found that frauds were more likely to be detected by tips (46\%) internal controls (23\%), accident (20\%), internal audit (19\%) and external audit (9\%). When financial reporting fraud occurs, the consequences to investors, the entity itself, other stakeholders and the fraud perpetrators often are severe. For example, Beasley et al. (2010) found that more than 75\% of the fraud firms filed for bankruptcy, became defunct, experienced a significant abnormal stock price decline or were delisted from a national stock exchange. They also find that a significant number of company executives were terminated or forced to resign, and that class action lawsuits and SEC enforcement actions against fraud perpetrators was common.

\section{CONCLUSIONS AND OPPORTUNITIES FOR FUTURE RESEARCH}

The review of accounting fraud literature suggests that overall, prior studies among others, examined the factors, motivations and antecedents of fraud at societal, organizational and individual levels. Others provided discussion on the fraud triangle and fraud diamond (Wolfe \& Hermanson, 2004). The fraud triangle (or fraud diamond) is portrayed as an efficient model for understanding antecedents to fraud. However, due to the growing complexity and creativity in financial markets and white collar crimes, some frame works may not fully capture the antecedents and factors of fraud. For example, there may be new demographic ${ }^{1}$, psychological and sociological antecedents such as managerial hubris (Magnan, Cormier \& Lapointe-Antune, 2010), personality and behavioural characteristics (Gillett \& Uden, 2005, Carpenter \& Reimers, 2005; Cohen, Ding, Lesage \& Stolowy, 2008); and other psychological factors (Duffied \& Grabosky, 2001) to fraud. This paper concurs with Zahra, Priem, and Rasheed (2005) to suggest further research to understand the motivational factors of fraud behaviours. Regarding the methodology adopted, most of the studies are based on evidence from the USA in which SEC Audit and Accounting Enforcement Releases (AAERs), financial restatements of companies at the General Accounting Office (GAO) and class action suits arising out of SEC actions and financial restatements. Institutional arrangements and legal frameworks differ around the world. Replication of studies based on publicly available data as is the case in the USA may not be possible in other countries like Nigeria. Moreover, results obtained from the studies reviewed may or may not be applicable in another context-outside of the USA. It may be more practical to employ the case study method which allows us to delve into the rich stories underlying each instance of accounting fraud- enabling a deeper investigation of the context surrounding each fraud case. The review also identified a gap for which future research will need to fill: the absence of any link to the extent to which financial statement auditors could adopt forensic accounting techniques or work with forensic accountants to enhance the probability of detecting financial reporting fraud in a timely, cost effective manner, even in the absence of specific fraud allegations.

\section{REFERENCES}

[1] Abbott, L.J., Parker, S. and Peters, G.F. (2004). Audit Committee Characteristics and Restatements. Auditing: A Journal of Practice and Theory, 23 (March): 69-88.

[2] Advisory Committee on the Auditing Profession (ACAP). (2008). Final Report of the Advisory Committee on the Auditing Profession. Washington, DC: United States Department of the Treasury.

[3] Albrecht, C., Albrecht, W., Dunn, J. (2001). Conducting a Pro-Active Fraud Audit: A Case Study. Journal of Forensic Accounting, 2, 203-218.

[4] Albrecht, W., Albrecht, C., and Albrecht, C. (2004). Fraud and Corporate Executives: Agency, Stewardship and Broken Trust. Journal of Forensic Accounting, 5, 109-130.

[5] American Institute of Certified Public Accountants (AICPA). (2002). Statement on Auditing Standards No. 99: Consideration of Fraud in a Financial Statement Audit. New York, NY: AICPA.

[6] Association of Certified Fraud Examiners (ACFE). (2008). Report to the Nation on Occupational Fraud and Abuse. Austin, TX: ACFE.

[7] Beasley, M.S. (1996). An Empirical Analysis of the Relation between the Board of Director Composition and Financial Statement Fraud. The Accounting Review. 71(4):443-465.

\footnotetext{
1 Tillman and Inderguard (2008:49 -50) cite the changed role and demographics of CFOs from the late 1990s which "had given birth to wheeler-dealer finance officers, instrumental in such master-of-the universe activities as negotiating mergers and acquisition. CFOs tossed aside their green eyeshades and turned to more creative pursuits... ability to find new finance and accounting tricks (Kahn, 2002). In some cases, this also meant participating in accounting frauds".
} 
[8] Beasley, S. M., Carcello, J. V. and Hermanson, D. R. (2010) Fraudulent Financial Reporting: 1997-2007: An Analysis of U.S. Public Companies. Research Report, COSO.

[9] Becker, C. L., DeFond, M. L. Jiambalvo, J. and Subramanyan, K.R. (1998). The Effect of Audit Quality on Earnings Management. Contemporary Accounting Research 15 (1): 1-24.

[10] Bell, T. B. and Carcello, J. V. (2000). A Decision Aid for Assessing the Likelihood of Fraudulent Financial Reporting. Auditing: A Journal of Practice and Theory 19(1): 169-184.

[11] Beneish, M.D. (1999). Incentives and Penalties Related to Earnings Overstatements that Violate GAAP, The Accounting Review, 74(4): 425-57.

[12] Black, W. K. (2005). Control Frauds' as Financial Super-Predators. The Journal of Socio Economics 34, 734-55.

[13] Bloomfield, R. J. (1997). Strategic Dependence and the Assessment of Fraud Risk: A Laboratory Study. The Accounting Review 72 (4): 517-538.

[14] Bonner, S. E., Palmrose, Z.V. and Young, S. M. (1998). Fraud Type and Auditor Litigation: An Analysis of SEC Accounting and Auditing Enforcement Releases. The Accounting Review, 73(4): 503-532.

[15] Brazel, J., Carpenter, T. and Jenkins, G. (2007). A Field Investigation of Auditors' Use of Brainstorming in the Consideration of Fraud. Working Paper, North Carolina State University

[16] Brazel, J., Jones, K. and Zimbelman, M. (2009). Using Non-Financial Measures to Assess Fraud Risk. Journal of Accounting Research, 47(5): 1135-1166.

[17] Brennan, N. and Hennessy, J. (2001). Forensic Accounting. Dublin: Round Hall Sweet \&Maxwell.

[18] Burgstahler, D. and Eames, M. (2006). Management of Earnings and Analysts' Forecasts to Achieve Zero and Small Positive Earnings Surprises. Journal of Business Finance \& Accounting 33(5-6): 633-652.

[19] Carcello, J. V. and Nagy, A. L. (2004). Audit Firm Tenure and Fraudulent Financial Reporting. Auditing: A Journal of Practice and Theory 23 (September): 55-69.

[20] Carcello, J. V. and Hermanson, R. H. (2008). Fraudulent Financial Reporting: How Do We Close the Knowledge Gap? Retrieved from https://pdfs.semanticscholar.org/f4bf/b3c2730f6cceab7d3d957aed3776da96738f.pdf on 17/04/2017

[21] Carcello, J., and Nagy. A. (2002). Auditor Industry Specialization and Fraudulent Financial Reporting. Proceedings of the Deloitte \& Touche / University of Kansas Symposium on Auditing Problems: Fraud and the Audit Process.

[22] Cressey, D. (1953). Other People's Money: A Study in the Social Psychology of Embezzlement. Glencoe: IL, Free Press.

[23] Dechow P. M. and Skinner D. J. (2000). Earnings Management: Reconciling the Views of Accounting Academics, Practitioners, and Regulators. Accounting Horizons, 14(2):235-250.

[24] Dechow, P.M., Sloan, R.G. and Sweeney, A.P. (1996). Causes and Consequences of Earnings Manipulations: An Analysis of Firms Subject to Enforcement Actions by the SEC. Contemporary Accounting Research, 13(1): 1-36.

[25] du Toit, E (2008) Characteristics of Companies with a Higher Risk of Financial Statement Fraud: A Survey of the Literature. Available at http://repository.up.ac.za/handle/2263/9141 on 12 March 2017.

[26] Erickson, M., Hanlon, M. and Maydew, E. (2006). Is There a Link Between Executive Equity Incentives and Accounting Fraud. Journal of Accounting Research, 44(1): 113-143.

[27] Fama E. F. and Jensen, M. C. (1983). Separation of Ownership and Control. Journal of Law and Economic 26(2): 301-325.

[28] Farber, D. (2005). Restoring Trust after Fraud: Does Corporate Governance Matter? The Accounting Review 80 (2): 539-561.

[29] Feroz, E., Park, K. and Pastens, V. (1991). The Financial and Market Effects of the SEC's Accounting and Auditing Enforcement's Releases, Journal of Accounting Research, 29, 107-42.

[30] Francis, J. R., Maydew, E. L. and Sparks, H. C. (1999). The Role of Big 6 Auditors in the Credible Reporting of Accruals. Auditing: A Journal of Practice and Theory 18 (Fall): 17-34.

[31] Gao, L., and Srivastava, R. P. (2008). The Anatomy of Management Fraud Schemes: Analyses and Implications. Working paper, University of Nebraska and University of Kansas.

[32] Guy, D.M., and Pany, K. (1997). Fraud in a Financial Statement Audit, working paper, AICPA, New York.

[33] Healy, P.M. and Wahlen, J.M. (1999). A Review of the Earnings Management Literature and its Implications for Standard Setting. Accounting Horizons 13(4): 365-383.

[34] Heiman, V. (1990). Auditors' Assessments of the Likelihood of Analytical Review Explanations. The Accounting Review (65): 870-890.

[35] Hogan, C. E., Rezaee, Z., Riley, R. A. and Velury, U. (2008). Financial statement fraud: Insights from the academic literature. Auditing: A Journal of Practice \& Theory 
[36] Iyer, V. M. and Rama, D.S. (2004). Clients' Expectations on Audit Judgments: A Note. Behavioral Research in Accounting 16 (1): 63-75.

[37] Kahn, J. (2000). The Chief Freaked out Officer. Fortune, December, 197

[38] Kedia, S. (2006). Do Executive Stock Options Generate Incentives for Earnings Management. National Bureau of Economic Research, Retrieved from http://www.nber.org/ confer/2003/URCCFS03/kedia.pdf

[39] Kinney, W.R. and McDaniel, L.S. (1989). Characteristics of Firms Correcting Previously Reported Quarterly Earnings. Journal of Accounting and Economics. February, 71-94.

[40] Klein, A. (2002). Audit Committee, Board of Director Characteristics, and Earnings Management. Journal of Accounting \& Economics 33(3): 375-4000.

[41] KPMG, (2004). What Boards Need to Know About Financial Statement Fraud. Across the Board , October, $5-7$.

[42] Levitt, A. (1998). The "numbers game". Speech delivered at New York University Law and Business Centre. Retrieved from http://www.sec.gov on $7^{\text {th }}$ July, 2015.

[43] Libby, R. and Frederick, D. M. (1990). Experience and the Ability to Explain Audit Findings. Journal of Accounting Research, 28, 348-367.

[44] Loebbecke, J., Eining, M. and Willingham, J. (1989). Auditor's Experience with Material Irregularities: Frequency, Nature, and Detectability. Auditing: A Journal of Practice and Theory, 9, pp. 1-28.

[45] Myers, J.N., Myers, V. and Omer, T.C. (2003). Exploring the Term of the Auditor-Client Relationship and the Quality of Earnings: A Case for Mandatory Auditor Rotation? The Accounting Review 78, 779800 .

[46] National Association of Certified Fraud Examiners. (1993). Cooking the Books: What Every Accountant Should Know about Fraud. New York: NASBA.

[47] National Commission on Fraudulent Financial Reporting (NCFFR). (1987). Report of the National Commission on Fraudulent Financial Reporting. New York: AICPA.

[48] National Commission on Fraudulent Financial Reporting. (1987). Report of National Commission on Fraudulent Financial Reporting. New York: AICPA.

[49] Nelson, M. W., Elliott, J. A. and Tarpley, R. L. (2003). How are Earnings Managed? Examples from Auditors, Accounting Horizons (Supplement): 17-35.

[50] Newman, P., Rhoades, S. and Smith, R. (1996). Allocating Audit Resources to Detect Fraud. Review of Accounting Studies 1(2): 161-182.

[51] Peng, L. and Ailsa, R. (2006). Executive Pay, Earnings Manipulation and Shareholder Litigation. Social $\begin{array}{lllll}\text { Science Research Network, } & 2006\end{array}$ http://papers.ssrn.com/sol3/papers.cfm?abstract_id=488148-29k

[52] Persons, O. (1995). Using Financial Statement Data to Identify Factors Associated with Fraudulent Financing Reporting. Journal of Applied Business Research, 11(3): 38-46.

[53] Rezaee, Z. (2002). Causes, consequences and deterrence of financial statement fraud. Critical Perspectives on Accounting 16(3):277-298.

[54] Rezaee, Z. (2005). Causes, Consequences, and Deterrence of Financial Statement Fraud. Critical Perspectives on Accounting, 16(3), 277-298.

[55] Richardson, S., Tuna, I. and Wu, M. (2002). Predicting Earnings Management: The Case of Earnings Restatements. Social Science Research Network, Retrieved November 25, 2005 http://ssrn.com.jerome.stjohns.edu:81/abstract $=338681$

[56] Spathis, C., Doumpos, M. and Zopounidis, C. (2002). Detecting Falsified Financial Statements: A Comparative Study Using Multicriteria Analysis and Multivariate Statistical Techniques. The European Accounting Review, 11(3): 509-535.

[57] Smith, J. F. and Kida, T. (1991). Heuristics and Biases: Expertise and Task Realism in Auditing. Psychological Bulletin (109): 472-489.

[58] Summers, S.L. and Sweeney, J.T. (1998). Fraudulently Misstated Financial Statements and Insider Trading: An Empirical Analysis. The Accounting Review.73(1):131-46.

[59] Telbergh, R. (2004). A Joint Effort to Fight Corporate Fraud, Journal of Accountancy, 197 (4), 53-56.

[60] Tillman, R. and Indergaard, M. (2007). Corporate Corruption in the New Economy. International Handbook of White-Collar and Corporate Crime, edited by Henry Pontell and Gilbert Geis. Springer.

[61] Wilks J., and Zimbelman, M. (2004). Decomposition of Fraud Risk Assessments and Auditors' Sensitivity to Fraud Cues. Working Paper. Brigham Young University.

[62] Wolfe, D. and Hermanson, D. (2004). The fraud diamond: considering the four elements of fraud. The CPA Journal, December, 34-37.

[63] Young, M.R. (2000). Accounting Irregularities and Financial Fraud. San Diego: Harcourt Inc.

[64] Zahra, S. A., Priem, R. L. and Rasheed, A. A. (2005). The Antecedents and Consequences of Top Management Fraud. Journal of Management, 31(6): 803 -828. 